OBITUARY

\title{
Basil Edwards: A Scholar, a Mentor and a Friend 1930-2014
}

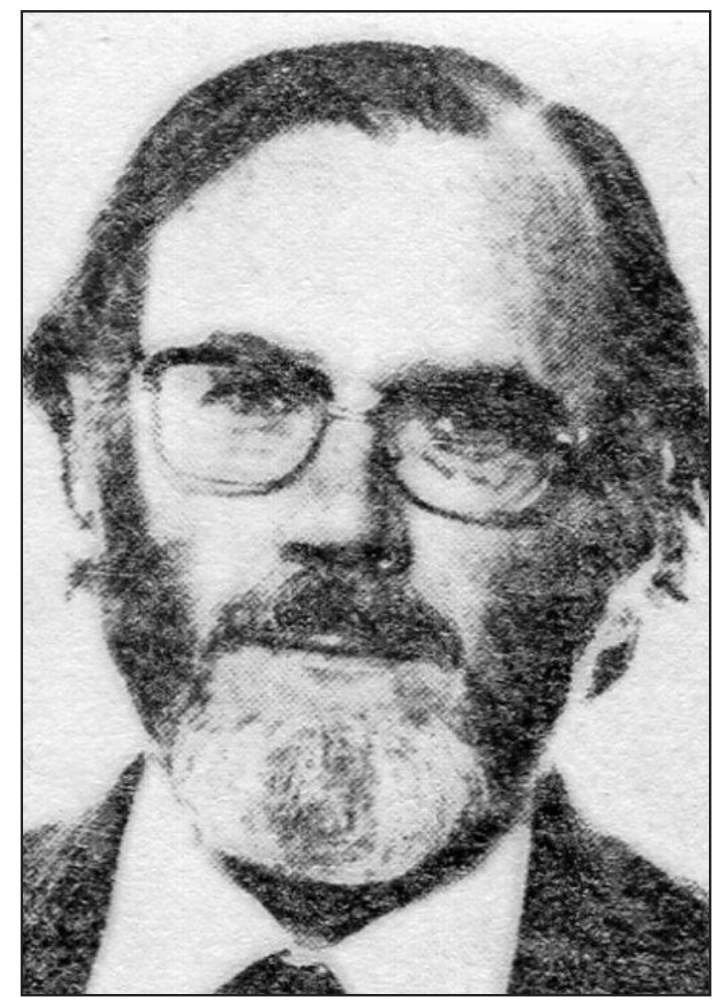

\section{UNISA $\cong$}

Fundamina

Volume 21 | Number 1 | 2015

pp 213-215
Doi: 10.17159/2411-7870/2015/v21n1a12 Print ISSN 1021-545X/ Online ISSN 2411-7870 (C) Unisa Press 
With the passing of Professor AB Edwards, South Africa lost a great legal scholar. I lost a mentor and a friend.

I first met Professor Edwards (as I continued to call him after his retirement) in 1984 when I was appointed as a research assistant in the then Department of Legal History, Comparative Law and Legal Philosophy. One of my first tasks was to assist in checking references for his work on Paulus Voet, which would later be published as The Selective Paulus Voet (Fundamina Editio Specialis, University of South Africa, 2007). During that time, I translated chapters from his PhD Thesis (University of Cape Town, 1984) from English into Afrikaans - a daunting task for a young research assistant, but giving me my first glimpse of the great scholar that he was. Two years later, I became a permanent member of the Department with Professor Edwards as its Head, and sometime later he became my doctoral supervisor. All in all, I had known him for thirty odd years, yet when I was approached to write this obituary, I realised at once how much and how little I knew about him.

Professor Edwards was a very private person. I know very little about his life history, save for a few facts that had emerged through the years. I know that he came to law somewhat late in life, having first trained as a scientist and worked as a pharmacist on the Zambian copper mines. It was during that time that he started studying law through the University of South Africa, where he would later become a Professor of Law. Considering the age difference between us, as well as our very different backgrounds (he being of Scots origin and my having grown up on a farm in the Eastern Cape with Afrikaans as my mother tongue), it is quite remarkable that we forged not only a very good professional relationship, but also a lasting friendship based on what I now know was huge mutual respect.

Professor Edwards was a true scholar. Well versed in legal history, legal philosophy and many other areas of the law, he relished the challenges posed by private international law, a subject area that can be baffling yet immensely rewarding, for the patient researcher. He understood that private international law could not be mastered in a hurry. He once said that Theo van Wijk, erstwhile Vice-Chancellor of Unisa, had written the following comment on one of his assignments (while he was studying for his BA LLB through Unisa): "Read more, think more, write less." Professor Edwards's scholarship in private international law encapsulates this: his writing reveals the intricacies of cross-border litigation, yet he advances his views with the clarity and authority that come from having carefully and systematically thought through a myriad potential permutations. His greatest contribution lies in the thorough historical and comparative research that informed his views on private international law questions. Professor Edwards expected high standards of his students, both undergraduate and postgraduate, but he set the bar much higher for himself.

He made a substantial contribution to South African law and legal literature. He was responsible for the chapters on "The Idea of Law", "Legal Theory", "The 
History of South African Law", "Sources of South African Law" and "Public and Private International Law", as well as, in conjunction with Professor Joan Church, the chapter on "Introduction to Indigenous Law and the Comparative Method", in the 1500 page tour de force, Introduction to South African Law and Legal Theory (2nd ed, Butterworths, Durban,1995 (repr: 1997)). He also authored the monographic LAWSA title, Conflict of Laws (Butterworths, Durban, 1993). Apart from numerous articles (including his inaugural lecture, "Choice of law in delict: Rules or approach?” (1979) 96 SALJ 48), notes and case comments, he participated in a number of Festschriften, which saw him unearth gems like Hughes $v$ Wrankmore ((1813-1814) Court of Appeals for Civil Cases at the Cape of Good Hope), an early international insolvency case. The Selective Paulus Voet (in collaboration with Dawie Kriel and with assistance from Paul du Plessis, Rena van den Bergh and Gardiol van Niekerk), was his last academic publication and perhaps the greatest of them all. The final published work contains a translation of those sections of Paulus Voet's De Statutis Eorumque Concursu Liber Singularis (Amstelodami, 1661) that are relevant to modern conflict of laws. These sections are placed in historical perspective within the context of the rise and fall of statutism in Western Europe, Great Britain, the United States of America and South Africa. The work concludes with a brief appraisal of Paulus Voet's legacy in South African law.

Professor Edwards worked very hard - there is no other way to state this fact. When he received funding to travel overseas for research purposes, he spent very little time away from that research. I recall his once explaining to me that he was unable to attend the Wimbledon final, which, having been rained out on the Sunday, had been moved to the Monday. Although he could have gone on the Monday (his ticket was valid), he had to get back to his research. Such was his commitment, though I think in later years he regretted missing that final!

Professor Edwards was my academic mentor. He would probably not have described our professional relationship in those terms, since there was no official appointment as mentor, but the impact he had on my career was immense and his scholarship will continue to influence my writing. He was meticulous in commenting on everything I wrote early on; how I now regret not having saved just one of those handwritten notes. When he decided that the title of my thesis should be all of twenty-two words long, I did not object - although it was quite impossible to print the full title on the back!

In later years, he became a very dear friend, whom I would visit when I was in Cape Town. He loved to reminisce about the "Unisa days" and was still very much interested in everyone's life and career. He remembered my birthday, without fail. I shall miss him. 